\title{
An Overview on Lambda, Epsilon, Kappa, Iota and Zeta Variants of Covid-19 and its Probability to Merge with Delta \& Delta Plus, why it is a Concern
}

\author{
Majid Monajjemi 1,*(D), Hakan Sezgin Sayiner ${ }^{2}$, Fatma Kandemirli ${ }^{3, *(\mathbb{D})}$, Fatemeh Mollaamin ${ }^{3(\mathbb{D})}$ \\ Department of Chemical engineering, Central Tehran Branch, Islamic Azad University, Tehran, Iran \\ Department of Clinical Infectious Diseases and Medical Microbiology, Faculty of Medicine, Adiyaman, Turkey \\ 3 Department of Biomedical Engineering, Faculty of Engineering and Architecture, Kastamonu University, Kastamonu, \\ Turkey \\ * Correspondence: m_monajjemi@srbiau.ac.ir (M.M.); fatma_kandemirli@yahoo.com (F.K.);
}

Scopus Author ID 670181068

Received: date; Revised: date; Accepted: date; Published: date

\begin{abstract}
COVID-19 is caused by the virus SARS-CoV-2 that belongs to the Corona groups. The subgroups of the coronavirus families are $\alpha, \beta, \gamma$, and $\delta$ coronavirus. On June 15,2021 , the string $\lambda$ of SARS-CoV-2 was evaluated as a variant of interest via the World Health Organization. This string has a high prevalence in some parts of South American countries, but it occurred only occasionally in Brazil. This study confirms that mutations in the $\lambda$-spike protein can be destroyed the neutralizing antibodies and increase infectivity. Coronaviruses such as SARS-CoV-2 have an evolutionary superpower called "recombination" which permits the mixing of their genomes into novel combinations. Unlike regular mutation, which precedes slowly one change at a time, recombination can produce whole changes in a coronavirus genome. Although right now, $\delta$ - variant is a concern, a mixing of $\lambda$ with other variants such as $\delta$-variant is much more of a concern compared to alone variants. There is another item: the recombination can arise within the sample after it was taken from the infected person, not while it was inside their body.
\end{abstract}

Keywords: COVID-19; Lambda coronavirus; Epsilon coronavirus; Kappa coronavirus; Iota coronavirus; Spike proteins.

(c) 2021 by the authors. This article is an open-access article distributed under the terms and conditions of the Creative Commons Attribution (CC BY) license (https://creativecommons.org/licenses/by/4.0/).

\section{Introduction}

\subsection{Coronaviruses or subfamily.}

Subfamily Corona has enveloped a positive-sense m-RNA virus that includes known RNA genomes with a length of around $30 \mathrm{~kb}$. Coronaviruses are important issues in recent years for any investigation to help humanity. Particularly virulent forms have emerged from their natural animal hosts and threaten human communities [1,2]. Nowadays, the new family of coronaviruses has emerged in China through living animals in the markets. Structural and genetic biological information can help us understand these dangerous foes and hopefully develop new ways to fight them [3,4]. Coronaviruses (containing strains) are a family's group of viruses known for diseases in mammals and birds. In human life, it is typically spread through airborne droplets of any fluids produced via infected individuals. Coronavirus consists of several genomes combined with a huge RNA strand. Those genomes raid to the cells and 
direct the synthesis of two large polyproteins containing the machinery the viruses need for replicating new viruses [2-4].

Many different lineages are not variants of concern or interest. These are grouped as 'Other' on this chart. As the proportions of concern variants and interest variants increase, the proportion of other lineages will decrease. Variants of concern and variants of interest include: B.1.1.7 (alpha), B.1.351 (beta), P.1 (gamma), B.1.617.2 (delta), B.1.427 (epsilon), B.1.429 (epsilon), B.1.526 (iota), B.1.525 (eta), B.1.617.1 (kappa) and B.1.617.3. The $\lambda$-SARS-CoV-2 variant, also known as C.37, is a variant of SARS-CoV-2 first detected in Peru ( August 2020) and was also named $\lambda$-variant by the World Health Organization On June 14, 2021. This kind of virus has been spread to at least 25 countries worldwide and is known to be more resistant to neutralizing antibodies than other strains. This variant could be more infectious and resistant to vaccines than the Alpha, Beta, Gamma, and even Delta variants [1-7]. The Lambda variant also contained a novel deletion $(\Delta 246-252)$ and multiple non-synonymous mutations (L452Q, F490S, G75V, T76I, T859N, and D614G) in the gene that encodes the viral spike protein $[3,4]$. The C.37 -variant (Lambda variant) is produced by a deletion in the ORF1a gene $(\Delta 3675$ 3677). Moreover, this variant exhibits a new deletion and multiple non-synonymous mutations in the spike genes, including $\Delta 246-252$, G75V, T76I, L452Q, F490S, D614G, and T859N) [35]. The mutations F490S and L452Q can occur in the RBD zone, and the F490S assists in decreasing susceptibility to antibodies neutralization. The isolate 203 Labresis exhibits eight several of C.37 lineages mutations and nineteen extra mutations in members of this lineage. The 203/LABRESIS sequences were aligned with extra quality, including whole genome sequences: from Brazil (1), Argentina (15), Chile (25), and Peru (25) available in the EpiCoV database in GISAID for performing phylogenetic tree [4-6].

The most spread of the $\lambda$-variant has been explored, especially in South American countries. This novel virus is quickly prevalent and is associated with other variants, particularly the delta variant. It is agreeable with the health care system reports about increasing deaths in those countries such as Chile, Peru, Ecuador, and Argentina. Health Organization evaluates whether the $\lambda$-variant is more pathogenic or transmissible compared with other variants. In other words, there is uncertain information about its potential to evade the effect of available vaccines [5,6]. The novel $\Delta 246-252$ mutations for making a new spike protein might be evaluated through their effects with host interaction. This first report of the $\lambda$ SARS-CoV-2 variant in Chile, Peru, Ecuador, Argentina, and particularly Brazil raises concern regarding the possible dissemination of this lineage in the region. Moreover, fast spread among those countries indicates that this variant has a considerable potential to become a variant of concern [7]. As shown in figure 1, $\lambda$-SARS-CoV-2 has 7 mutations in its spike protein, while the delta variant has three; therefore, $\lambda$-variant could have a range of consequences, such as the possibility of fast transmissibility or increasing resistance to antibodies. It is the coronavirus spike protein that binds to a human protein to initiate the process of infection. Those variants were first identified in the UK and then in California combined into a heavily mutated hybrid. This could signal a new phase of the covid-19 pandemic, as more hybrid variants may have emerged. Coronaviruses such as SARS-CoV-2 have an evolutionary superpower called "recombination," which permits the mixing of their genomes into novel combinations. Unlike regular mutation, recombination can produce whole changes in a coronavirus genome in one single swoop. It was reported on February 02 at a virtual conference organized by the New York Academy of Sciences. In a presentation about the outbreak in Los Angeles, Bette Korber of Los Alamos National Laboratory in New Mexico said: "We found at least a single 
recombinant." She went on to add further details. For example, she showed a graphical representation of the viral genome showing clearly that it is a mosaic of sequences from two different lineages, which is hard to explain any other way than recombination. This is more likely to occur where the two viruses are closely related but has been documented between quite distantly related coronaviruses. So it isn't impossible that SARS-CoV-2 could recombine with a common-cold-causing coronavirus, with unknown consequences. Unlike regular mutation, where changes accumulate one at a time, which is how variants such as B.1.1.7 arose, recombination can bring together multiple mutations in one go. These don't confer any advantage to the virus most of the time, but occasionally they do [5-7].

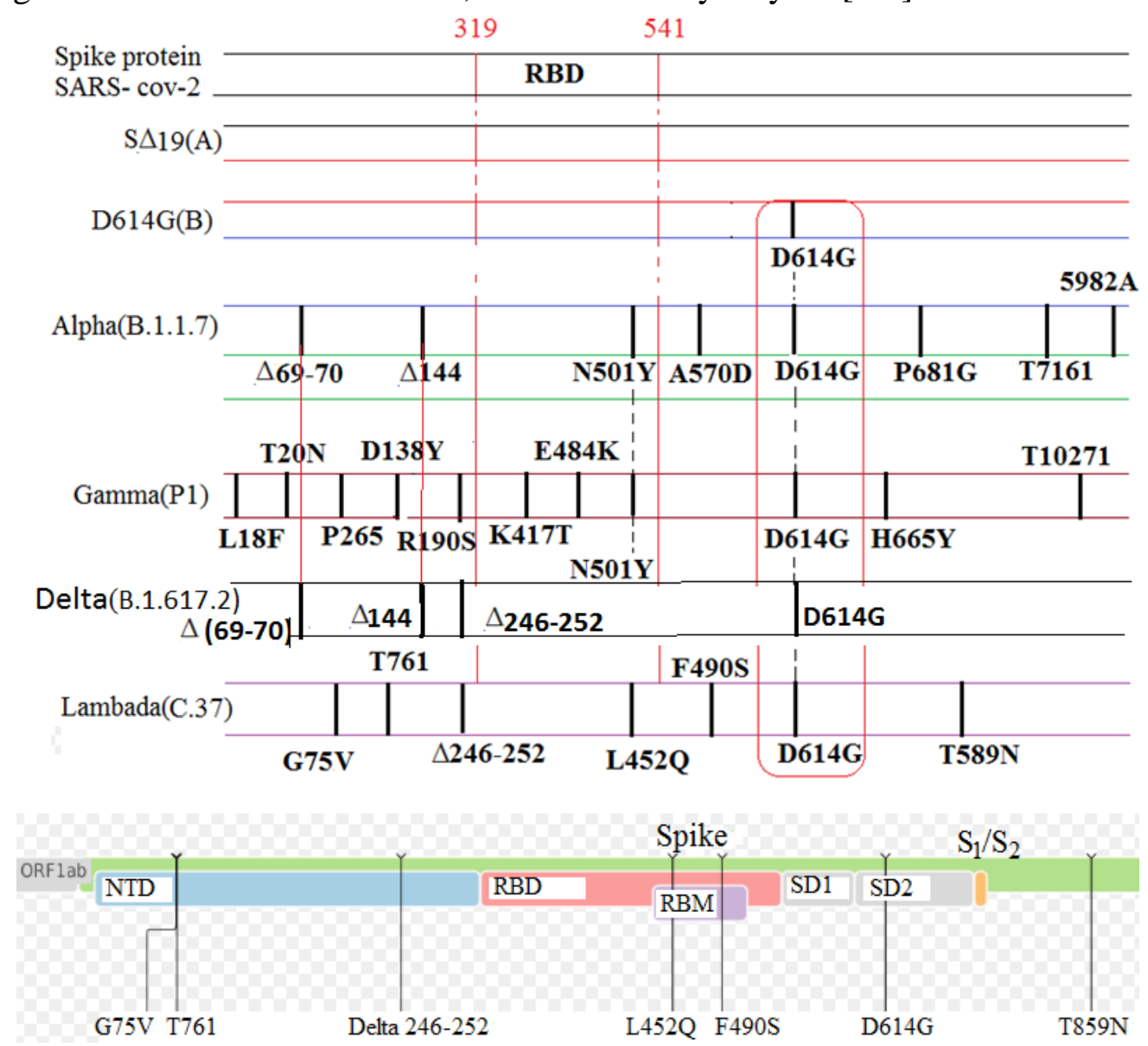

Figure 1. Schematic diagram of the Various SARS-CoV-2 spike proteins and the related variants.

As it can be seen in Figure 1, the $\lambda$-genome has the following amino acid mutations, all of which are in the spike protein code: G75V, T76I, $4246-252$, L452Q, F490S, D614G, and T859N. The F490S mutation has already been associated with reduced susceptibility to antibodies generated in patients who had recovered from COVID; therefore, F490S has favorable cooperation with its reduced susceptibility to antibody neutralization. This means antibodies generated from being infected with the original Wuhan strain of COVID aren't quite as effective at neutralizing Lambda. The L452Q's $\lambda$ - mutation is at the same position in the spike protein same as a mutation found in the $\delta$-variant, where this mutation in $\delta$-variant not only increases the ability of the virus to infect cells but also promotes immune escape meaning the antibodies vaccines generate less likely to recognize it[8-10]. These mutations are in the RBD, a segment of the related spike protein that binds to our human cells. Via evaluating the first information of $\lambda$-spike protein predicts it has increased infectivity that means it is more quickly able to infect cells than the original Wuhan virus $a \& \beta$ variants. In other words, antibodies produced in people receiving the Sinovac (corona vaccine) were less potent at 
neutralizing the spike protein of $\lambda$-variant than they were the Wuhan, $a \& \beta$ variants. Although there's not sufficient information yet that $\lambda$-variant is more infectious, the mutations it has suggested it's possible. Recently, it has been predicted that L452Q mutation in the $\lambda$-spike protein is due to its increased ability to infect cells. As well as the L452R mutation in the $\delta$-variant, this study suggests the L452Q mutation may bind more easily to the "ACE2 receptor", which is the gateway for SARS-CoV-2 to enter our cells. In addition, $\lambda$-spike protein mutations reduce the possibility of antibodies generated by Pfizer and Moderna's vaccines to neutralize the virus. Also, one mutation was shown to resist neutralization by antibodies from antibody therapy to some extent. The risk evaluation also suggests both $\lambda \& \delta$ can be considered as a priority $[11,12]$. As a result, it must be focused on $\lambda$-variant, while is it capable of outcompeting $\delta$ or mix with it for increasing the potential of this virus against any vaccination as much as possible. By this research, we will understand; this variant again highlights the risk of these mutations increasing the ability of SARS-CoV-2 to infect cells or disrupt existing vaccines and antibody drugs.

\subsection{Risks associated with $\lambda$-spike protein.}

The $\lambda$-variant is sometimes associated with higher transmissibility and resistance to antibodies. "Lambda has been associated with substantive rates of community transmission in multiple countries, with rising prevalence over time concurrent with increased COVID-19 incidence $[13,14]$. The $\lambda$-spike protein variant has a unique pattern of seven mutations from which L452Q is similar to the L452R mutation reported in the $\delta \& \varepsilon$ variants. Additional information confirms that the L452Q mutation of $\lambda$-variant has to be conferring similar properties to those described for the infectivity of the $\delta$ - variant. Public Health England reported that "there is no information that this variant causes more severe disease or presents the vaccines currently located any less effective." Knowing of the $\lambda$-variant is still completely low, but based on WHO official release, COVID-19 patients will generally exhibit one of these primary symptoms as pyrexia, dry cough, and exhaustion. Although the being infectious and transmission rate of the $\lambda$-variant hasn't been appointed yet, it has been found in about 30 countries [12]. While it is the dominant strain in Peru, accounting for over $80 \%$ of the cases, in Chile, it accounts for more than $31 \%$ of the samples from May and June. This variant has a large potential of transmissibility or resistance to neutralizing antibodies, and it already has an ongoing battle against the $\delta$-variant. $\lambda$-variant is still unclear how is a cause of concern due to lack of study, and also there was not yet clear evidence it was a more transmissible virus [11-14]. Currently, researchers have no clear response on this variant at the University of Chile, Santiago, studied the effect of $\lambda$-a variant on viral infectivity, but their results suggest that Lambda is more infectious than Gamma and Alpha and better able to escape the antibodies produced by vaccination. It is notable that both Pfizer's and Moderna's vaccines are based on mRNA technologies and, therefore, might be useful for $\lambda$-variant same as alpha and beta (Scheme 1).

\subsection{How do $\lambda$-variant arise and why concerning.}

Any kind of viruses like as $\lambda$-variant, alternately and frequently evolve via mutations; these evolving can appear anytime the virus replicates. Some of these changes do not produce a strong variant, and also, there is no effect, but some of them can make the virus more transmissible, enable it to cause more severe disease, or allow it to evade better the protection 
offered by vaccination (or mixing of these items). In countries with low vaccination rates, where humans are unvaccinated, the viruses can spread rapidly, and consequently, more harmful variants might emerge $[12,13]$. Therefore, the major concern of those variants is that they spread more quickly from human to human. Moreover, if a variant doesn't cause more severe illness, it can also lead to a quick rise in COVID-19 deaths if it spreads more easily, particularly in countries with low vaccination items. In table 1, a list of 90 kinds of wild-type and pseudo-virus mutant strains are listed for assisting the scientist in fasting obtaining the efficacy evaluation of neutralizing antibodies against mutant strains and the clinical use of vaccines $[14,15]$.

Table 1. Specific genetic markers are predicted to affect the transmission, diagnostics, therapeutics, or immune escape.

\begin{tabular}{|c|c|c|c|c|}
\hline Mutated & Variants Name & Spike Protein Substitutions & WHO Label & First Identified \\
\hline B.1.351 & & & Beta & \\
\hline B.1.1.7 & & & Alpha & \\
\hline B.1.427 & 20C/S:452R & L452R, D614G & Epsilon & United States-(California) \\
\hline B.1.429 & 20C/S:452R & S13I, W152C, L452R, D614G & Epsilon & United States-(California) \\
\hline B.1.525 & $20 \mathrm{~A} / \mathrm{S}: 484 \mathrm{~K}$ & $\begin{array}{l}\text { A67V, 69del, 70del, 144del, E484K, } \\
\text { D614G, Q677H, F888L }\end{array}$ & Eta & $\begin{array}{l}\text { United Kingdom/Nigeria - } \\
\text { December } 2020\end{array}$ \\
\hline B.1.526 & $20 \mathrm{C} / \mathrm{S}: 484 \mathrm{~K}$ & $\begin{array}{l}\text { L5F, D80G, T95I, Y144, F157S , D253G, } \\
\text { L452R , S477N , E484K, D614G, A701V, } \\
\text { T859N , D950H , Q957R }\end{array}$ & Iota & $\begin{array}{l}\text { United States (New York) - } \\
\text { November } 2020\end{array}$ \\
\hline B.1.620 & & $\begin{array}{l}\text { P26S,V126A,H245Y,S477N,E484K,D614 } \\
\text { G,P681H,T10271,D1118H, } \Delta 69- \\
\text { 70, } \Delta 144, \Delta 241-243\end{array}$ & & \\
\hline B.1.617.1 & $20 \mathrm{~A} / \mathrm{S}: 154 \mathrm{~K}$ & $\begin{array}{l}\text { H1101D, G142D, E154K, L452R, E484Q, } \\
\text { D614G, P681R, Q1071H }\end{array}$ & Kappa & India - December 2020 \\
\hline B.1.617.2 & & $\begin{array}{l}\text { T19R,G142D, } 4156, \\
\Delta 157, R 158 G, L 452 R, T 478 K, D 614 G, P 681 \\
\text { R,D950N }\end{array}$ & Delta & India \\
\hline B.1.617.2.1 & & $\begin{array}{l}\text { D614G,K417N,P861R,T19R,D950N,T478 } \\
\text { K,L452R, , } \Delta 157, \Delta 158\end{array}$ & Delta Plus & India \\
\hline B.1.617.3 & $20 \mathrm{~A}$ & $\begin{array}{l}\text { T19R, G142D, L452R, E484Q, D614G, } \\
\text { P681R, D950N }\end{array}$ & & India - October 2020 \\
\hline B.1.1.1 & C.37 & $\begin{array}{l}\Delta 246-252, \\
\text { G75V,T761,L452Q,F497s,T859N,D614G }\end{array}$ & Lambda & Peru \\
\hline P.1 & & & Gamma & Brazil \\
\hline P.2 & $20 \mathrm{~J}$ & E484K, F565L, D614G, V1176F & Zeta & Brazil - April 2020 \\
\hline
\end{tabular}

Variants of concern are $\alpha, \beta, \delta$ and $\gamma$, that they're more dangerous to people and although $\lambda$-variant isn't a variant of concern at present, this might be changed over time, due to rapidly spread in Peru, Ecuador, Chile, and Argentina. $\lambda$-variant has a considerable ability to become a variant of concern because researchers don't know whether $\lambda$-variant can put off the immune protection through COVID-19 vaccines. Recent studies suggest that $\lambda$-variant is more infectious than $\alpha, \beta$, and $\gamma$, and which this variant can be able to put over the antibodies produced after vaccination with this vaccine. Recent studies confirm that mutations in the $\lambda$ spike protein can be destroyed the neutralizing antibodies and increase infectivity. Although right now, $\delta$-variant is a concern, a mixing of $\lambda$ with other variants such as $\delta$-variant is much more of a concern compared to alone variants. The implications of the finding aren't yet clear because very little is known about the recombinant's biology. There is a hybrid is a mash-up of the B.1.1.7 variant first detected in Kent, UK, late last year, and the lesser-known B.1.429, which appears to have originated in southern California. Although most of these mutations won't have a significant effect on the virus, it gives an advantage to the virus by increasing its ability to replicate or evade the immune system. The occurrence of these mutations is down to the error-prone replication machinery that viruses use. RNA viruses, such 
as influenza and hepatitis $\mathrm{C}$, generate a relatively large number of errors each time they replicate. Interactions with the host cells and immune system determine the relative frequencies of the individual variants. These coexisting variants may affect how the disease progresses or how treatments work [12-15].

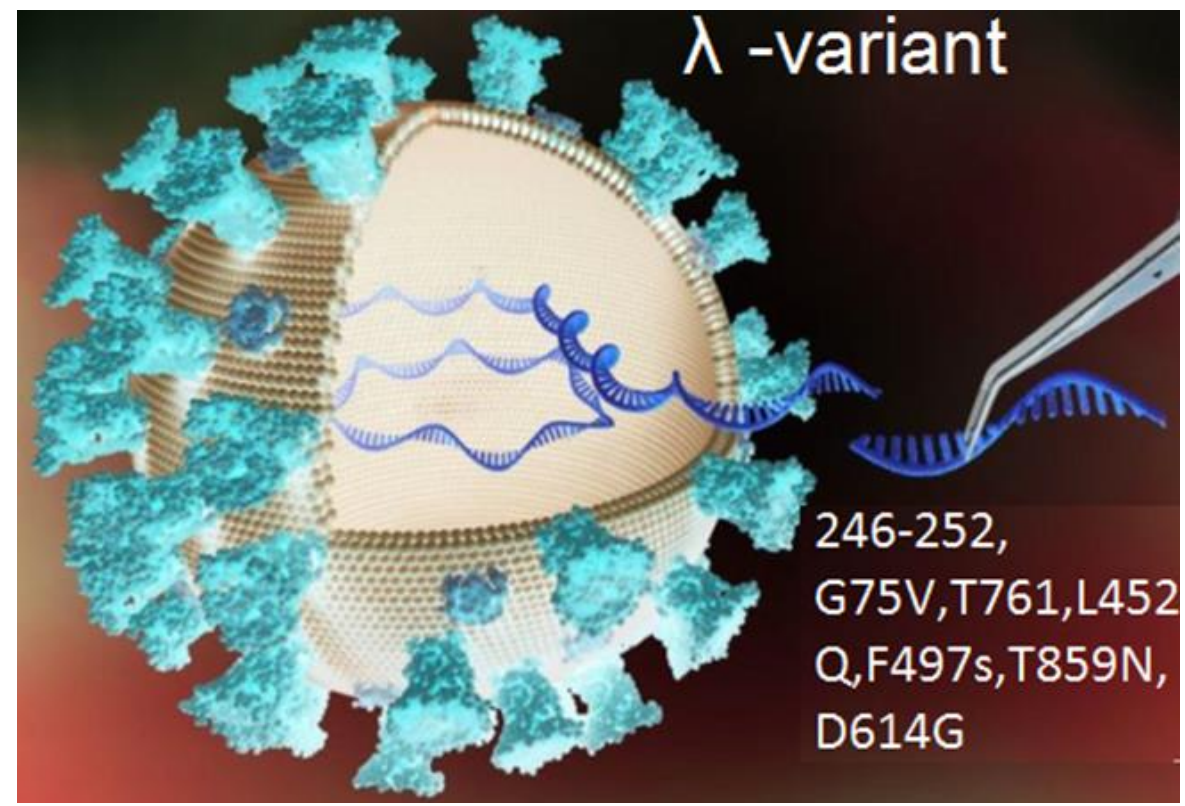

Scheme 1. Pfizer's and Moderna's vaccines are based on mRNA technologies.

\subsection{Problem of the Kappa variant.}

Kappa variant ( $\kappa$-variant) is a sub-lineage of B.1.617 variant, first reported from Maharashtra, India, in October 2020. This variant was subsequently identified as a triple mutant by the Indian government in late March 2021, as it had three mutations of interest. The sublineage B.1.617.1 is now known as $\kappa$-variant, while B.1.617.2 is known as the $\delta$-variant. The $\delta$ - variant, are responsible for the emergence of the second wave in India; it has been found in nearly 100 countries and is a global VOC. The third sub-lineage, B.1.617.3, has not been identified as either a VOI or a VOC. In simple terms, $\kappa$-variant is a sibling of Delta. However, as in a family, siblings could be very different from each other, which is exactly the case with $\kappa$-variant and $\delta$-variant. While $\delta$-variant has higher transmissibility, documented immune escape, and breakthrough infections, none of these properties have been documented for the $\kappa$-variant so far. $\mathrm{K}$-variant is not a major concern as of now. Although right now, $\kappa$-variant is a concern, a mixing of $\lambda$ with other variants such as $\delta$-variant and $\kappa$ variant is much more of a concern compared to alone variants. People fully vaccinated have a much lower risk of severe illness and death than unvaccinated people at risk from all coronavirus variants. Different variants are identified through their mutations in the virus's gene. An alteration in each of these RNA bases (that made of about 35,000 base pairs) makes a mutation, consequently changing the shape and properties of the virus function. The Delta variant consists of several mutations in the spike protein, where four of them are most important $[14,15]$. One of these is known as L452R, which was reported in March 2020 in Denmark firstly. This mutation has been shown to be more transmissible than wild-type strains and has also been related to reduced antibody influence and decreased neutralization during vaccination. The P681R's mutation has been related to chemical processes that might be enhanced transmissibility [12-15]. The D614G mutation first appeared in the US early in the 
pandemic. There is affirmation with a report of the Centers for Disease Prevention and Control (CDC), those variants with the mutations mentioned above spread more quickly compared with other variants of COVID-19. Another mutation in Delta is T478K that was appeared in around $60 \%$ of occurrences in variant B.1.1.222, was first detected in Mexico City and was included with high infectivity [16-21]. Public Health England stated Delta exhibits much more growth rating compared with alpha through several statistical and experimental analyses. Recently UK found that $62 \%$ of pandemic cases are Delta $[17,19]$. Consequently, by decreasing the Alpha pandemic, Delta cases rise day by day [22-25]. In addition, a variant of concern is pandemic. There is evidence of an increase in transmissibility, more severe disease, significant reduction in neutralization by antibodies generated during previous infection or vaccination, reduced effectiveness of treatments or vaccines, or diagnostic detection failures. Some of them are listed in Table 2. Variants of concern might require one or more appropriate public health actions, such as notification to WHO under the International Health Regulations, reporting to CDC, local or regional efforts to control spread, increased testing, or research to determine the effectiveness of vaccines and treatments against the variant [26-28].

Delta has continued to spread globally, including in the UK, India, and Mexico City, with a proportion of cases resulting in more severe disease and hospitalization. Here we estimate the effectiveness of the BNT162b2 and ChAdOx1 vaccines against Delta as compared to alpha. There were 14,000 symptomatic cases with Delta included in the analysis, 170 of whom were hospitalized. Overall hazard ratios for hospitalization among cases with Delta in vaccinated compared to unvaccinated individuals were 0.36 after one dose and 0.28 after two doses $[29,30]$. $\delta$-coronavirus genomes are the smallest known coronavirus genomes $(25,500-$ 26,900 bases), similar to that of another coronavirus: ORF1ab, spike, envelope, membrane, and nucleon-capsid. Both 5' and 3' ends contain short un-translated regions. The replicas ORF1ab encodes a number of proteins, including nsp3, nsp5, nsp12, and nsp13, and some proteins with unknown functions. However, review reverse transcription analyses show that PD-CoVs were present in the US swine as early as August 2013 [31,32]. The spread situation, virus' transmissibility, the effectiveness of vaccines, and Immune Evasiveness of the SARS-CoV-2 variants based on WHO reports are listed in table 2.

Table 2. Dominant mutants worldwide, the number of stars indicate the intensity amount.

\begin{tabular}{l|l|l|l|l} 
Variant & Lable Mutated & Transmissibility & effectiveness of vaccines & Immune Evasiveness \\
\hline Alpha & B.1.1.7 & $* * *$ & $\begin{array}{l}\text { Effects on vaccine } \\
\text { efficacy }\end{array}$ & confirm \\
\hline Beta & B.1.351 & $*$ & $* * *$ & confirm \\
\hline Gamma & P.1 & $* *$ & $* *$ & confirm \\
\hline Delta & B.1.617.2 & $* * * *$ & $* *$ & confirm \\
\hline Lambda & C. 37 & $* * * *$ & $* *$ & confirm
\end{tabular}

This study aims to find how to remove the problem with appearing anymore and further mutations of mRNA in coronavirus.

\section{Materials and Methods}

\subsection{Structural analysis.}

The polymerase B.1.429 / epsilon variant with an S2M11 + S2L20 Global Refinement [33] by classification with viral protein/immune system has been considered, and the $7 \mathrm{~N} 8 \mathrm{H}$ file has been extracted from the RCSB(Figure 2). The epsilon ( B.1.427/B.1.429) covid-19 was 
explored at the beginning of 2021 in California for the first(its infectivity has also been changed) [34]. The two lineages epsilon ( B.1. 427 /B.1.429) covid-19 share the same S mutations in the RBD but harbor different mutations in other SARS-CoV-2 genes [34]. The fast rise in the number of cases associated with the B.1.427/B.1.429 lineages led to their classification as a VOC by the US Centers for Disease Control and Prevention (https://www.cdc.gov/coronavirus/2019-ncov/cases-updates/variant-surveillance/variantinfo.html) [35].

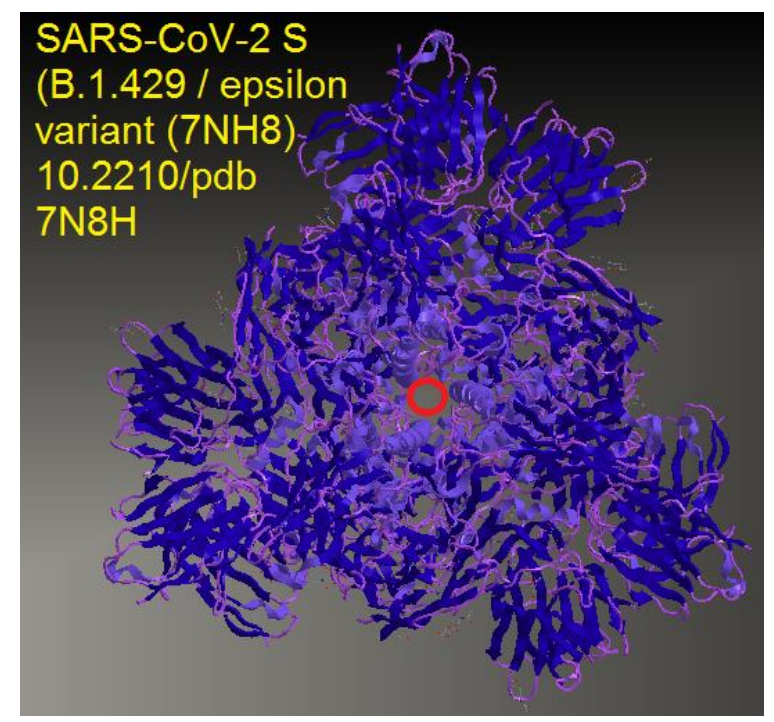

Figure 2. SARS-CoV-2 S (B.1.429 / epsilon variant) + S2M11 + S2L20 Global Refinement.

To assess the impact of the three mutations present in the B.1.427/B.1.429 S glycoprotein on neutralization potency of mRNA vaccine-elicited Abs against the G614 S and B.1.427 /B.1.429 S pseudo-viruses, Mccallum and coworkers [35] used plasma from 15 individuals who received two doses of the Moderna mRNA-1273 vaccine and as well as two doase doses of Pfizer/BioNTech BNT162b2 vaccine. All vaccines had substantial plasmaneutralizing activity against G614 SARS-CoV-2 S pseudo-typed viruses. Using a murine leukemia virus pseudotyping system, geometric mean titers (GMTs) showed that the average neutralization potency of the Moderna mRNA1273-elicited plasma was reduced 2.4-fold for B.1.427 /B.1.429 S (GMT: 178) compared with G614 S. Most of the recently risen coronavirus variants of interest or concern, Delta, kappa, epsilon, iota, and Lambda, are universally carrying a mutation in amino acid L452 of the Spike protein that helps the virus bind to host cells. In the epsilon variant, the Spike Protein Substitutions of L452R mutations (Table 1) may have triggered the emergence of several COVID-19 variants [36]. Unlike the epsilon variant with four more mutations in the Spike protein, in that newer variant (from the lineage B.1.232), the L452R mutation is the only one in the Spike protein that latches the virus onto cells to create a pathway to inject its genetic materials. The Spike proteins are what give the coronavirus its studded, crown-like appearance [36]. 7LWW pdb file from RCSB indicates triple mutant (K417N-E484K-N501Y) SARS-CoV-2 spike protein in the 1-RBD-up conformation (SGSAS-D614G-K417N-E484K-N501Y) that E484K exits in Eta variant [37] (Figure 3). The researchers found that the single $\mathrm{K} 417 \mathrm{~N}$ mutation provided substantial $\mathrm{mAb}$ resistance; however, it reduced the ability of the virus to bind to ACE2 by 6.4 -fold. The E484K mutation also provides neutralization resistance by forming salt bridges or hydrogen bonds, rendering antibodies ineffective. The N501Y mutation sharply increases binding affinity, and thus as such, when the three mutations are combined (K417N-E484K-N501Y), the new mutant strain 
is both more transmissible and more resistant to neutralization from a wide range of antibodies [38].

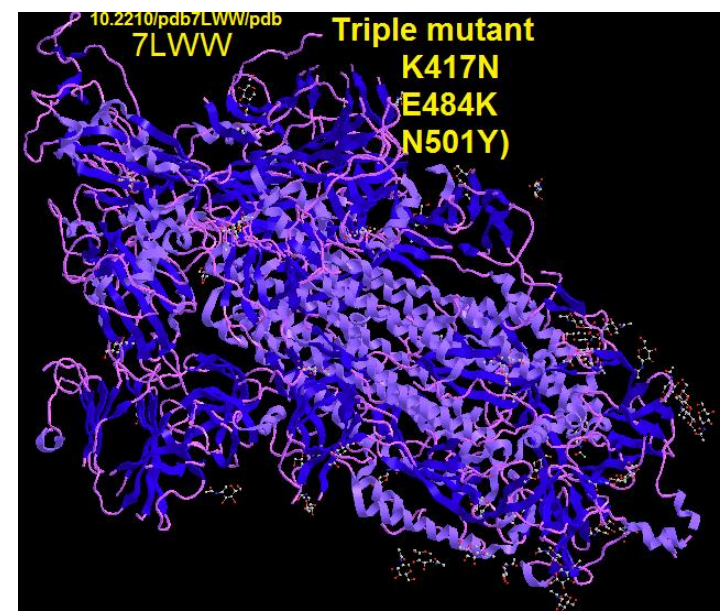

Figure 3. The triple mutant (K417N-E484K-N501Y) SARS-CoV-2 spike protein in the 1-RBD-up conformation (S-GSAS-D614G-K417N-E484K-N501Y).

Porcine delta-coronavirus $(\mathrm{PdCoV})$ has been analyzed due to the divergence of their envelope-anchored spike protein. This protein pushes the viral into host cells via first binding to host receptors by the S1 domain and, consequently, fusing host and viral membranes via the S2 subunit. Understanding the structure of spike proteins is critical for knowing cell entry and evolution of immunogenicity peptidase in covid-19 disease. S1 subunits from spikes consist of two subunits, first N-terminal and second C-terminal. Based on the virus, either one or both S1 domains can function as the receptor-binding domain (RBD) via binding to host receptors (Figure 4).

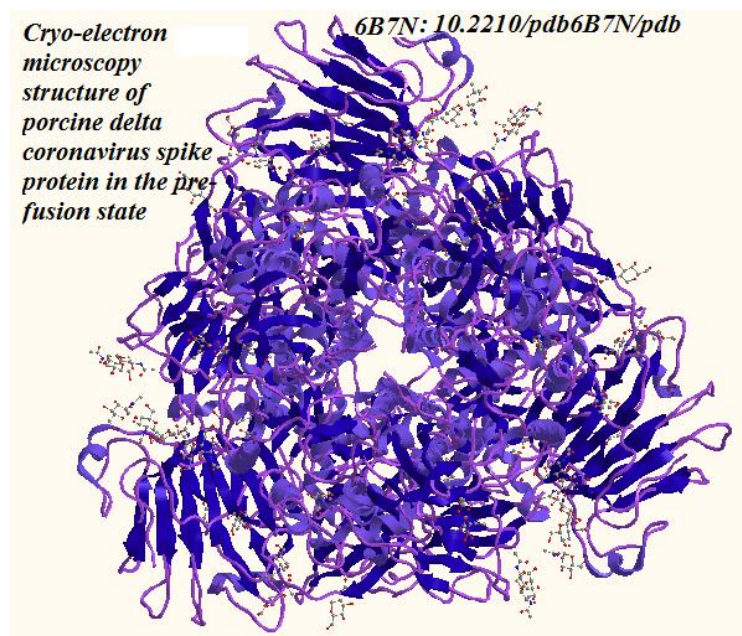

Figure 4. Cryo-electron microscopy structure of porcine delta coronavirus spike protein.

On the other side, the S1 domain from coronaviruses has different tertiary structures, but they share a structural configuration, indicating a general evolutionary and divergent evolution of S1-CTDs. Coronavirus S1-CTDs recognize either angiotensin-converting enzyme 2 or amino peptidase- $\mathrm{N}$ as their protein receptor, whereas -coronavirus S1-CTDs recognize ACE2 or dipeptide 4 . Hence, it has been predicted that coronavirus S1-NTDs originated from host gelatins and have undergone divergent evolution to recognize different receptors. The membrane fusion mechanism for coronavirus spikes is believed to be similar to those used by class 1 viral membrane fusion proteins. 
The overall architecture of - and -coronavirus spikes is similar to, albeit more complex than, influenza HA. Biochemical studies have identified parts of $\mathrm{S} 2$ that form six-helix bundle structures and likely correspond to HR-N and HR-C and another part of S2 that associates with membranes and likely corresponds to FP. It was demonstrated that -coronavirus spikes are heavily glycosylated, with S2 being more heavily glycosylated than S1, as a viral strategy for immune evasion. These studies on membrane fusion by - and -coronavirus spikes have suggested a common molecular mechanism for membrane fusion shared by coronavirus spikes and other class 1 viral membrane fusion proteins

\subsection{Docking and free energy calculations.}

BIOVIA_2020.DS2020Client software has been used for docking calculation, and a grid of $19 \AA$ was produced over the co-crystallized peptide-like inhibitors. Re-docking of the co-crystallized molecules was done for evaluating the docking project. The docked tool was based on a crystal system for calculating. The re-docking of structures and compounds has been built with $1.30 \AA$ and $0.80 \AA$ RMSD, respectively. Lower RMSD indicates that our docking methodologies are adequate and can be applied to search for small molecule inhibitors. Docking was done in three different modes, virtual screening followed by standard-precision (SP) and extra-precision (XP) docking using the Glide program. By this work, the iGEMDOCK has been applied. Through this software, the acceptable receptor can be defined for the binding site in whole spike proteins structures. This software can help to define the suitable binding site exactly. Following categories have been accomplished in docking, first; Preparing a few probable binding sites on the spike proteins surfaces, second, browsing and selecting the related spike proteins files. Third, defining the binding site's situation as a bounded ligand, Forth, defining the center of the binding sites via selected related ligands, and the end; setting the size of the binding sites and spiking protein radius from the selected ligand approximately. IGEMDOCK yields an analysis surrounding visualized tools and post-analysis tools for users, which can visualize the docked states, and categories through the protein-ligand interactions. Consequently, the prediction and scores of ligands might be saved in the output root. The minimum energies poses of each ligand would be outputted into the location of "best: Pose". These analysis tools are premeditated based on the analysis of those poses. Via looking for the bounded structures of some ligands, they might be selected via the estimated volume of the box of ligands. Cluster analysis is the partitioning of a data set into subsets. The data in each ideal subset will share some general traits. IGEMDOCK algorithm simulates the ligands based on interaction and atomic composition features. Interaction feature is extracted from the proteinligand interactions, and atomic composition is accounted atomic types in several functional groups. It is possible to specify the number of clusters for your data. Cluster estimation is the analysis of data ranges into subsets. The information in each subset will share some general properties. These are based on interaction and atomic combination aspects. Interaction aspects are extracted from the protein-ligand couples, and atomic combinations are calculated atomic types in various functional groups [39-41].

\subsection{M.D. simulations and gene mutation.}

Molecular dynamics modeling for polypeptide-ligand complexes were accomplished using the Desmond software. The OPLS and charm force fields were applied for modeling the interactions of the protein-small molecules. Long-range electrostatic forces were estimated 
using the Particle-mesh Ewald (PME) software with a grid spacing of $0.80 \AA$. Nose-Hoover thermometry and Martyna-Tobias-Klein method were applied for maintaining the temperature and constant pressure, respectively. The motion formula was considered using the multi-run RESPA by 4.0 fs time step for bonded and non-bonded interactions within a low cutoff. An outer time step of $5.0 \mathrm{fs}$ was used for non-bonded forces beyond the cutoff. Genotyping of the several mutations has been simulated based on table 1 to clear the mutation mechanism, which was performed by primer extension of PCR and then detected by matrix-assisted laser desorption ionization. PCR products were purified using the shrimp alkaline phosphatase method and extended by adding a homogeneous Mass-Extend primer as per the SequencerMass-Array protocol. Each gene coordinates are defined by its expression vector in an mRNA microarray experiment $[38,40]$.

\section{Results and Discussion}

\subsection{Simulations for interactions between the CoV2-RBD and the ACE2.}

It can be discussed about the polar and charged residues for many of the fraction and binding interfaces of CoV2-RBD and the ACE2. Moreover, electrostatic interaction has critical points for a complex formation. Distances among the two mentioned proteins are a key at the binding interfaces identified for the three representative models (Figure $5 \&$ Tables 1-3). The majority of those residues are preserved for models. The same simulations can be accomplished for the SARS-RBD/ACE2 complexes. Interestingly, the SARS-RBD counterpart in CoV2RBD did not form close contact with the ACE2 in related simulations. It is worthwhile to mention that the sequence identity between CoV2-RBD and SARS-RBD is low in this loop region, suggesting the loop region might be partially responsible for the difference in the receptor binding. The hydrogen bonds among the CoV2-RBD and ACE2 can be extracted using VMD program. It can be discussed that the number of hydrogen bonds fluctuated over time. Similar trends can be observed in the other simulations, suggesting that the binding became stronger as the simulation progressed. This work has been done based on our theoretical works [42-59]

Table 3. Antibody and Nucleocapsid antibody of human-derived anti-SARS-CoV-2 S protein RBD neutralizing.

\begin{tabular}{|c|c|c|c|c|}
\hline Molecule & Cat. No. & Species & Host & Product Description \\
\hline \multirow{7}{*}{ ACE2 } & AC2-R5246 & Rat & HEK293 & Rat ACE2 / ACEH Protein, His Tag (MALS verified) \\
\hline & AC2-H82E6 & Human & HEK293 & Biotinylated Human ACE2 / ACEH Protein, His,AvitagTM \\
\hline & AC2-H5257 & Human & HEK293 & Human ACE2 / ACEH Protein, Fc Tag (MALS verified) \\
\hline & $\mathrm{AC} 2-\mathrm{C} 52 \mathrm{H} 7$ & Cynomolgus & HEK293 & Cynomolgus ACE2 / ACEH Protein, His Tag \\
\hline & AC2-H82F9 & Human & HEK293 & Biotinylated Human ACE2 / ACEH Protein, Fc,AvitagTM \\
\hline & AC2-M5248 & Mouse & HEK293 & Mouse ACE2 / ACEH Protein, His Tag (MALS verified) \\
\hline & AC2-H52H8 & Human & HEK293 & Human ACE2 / ACEH Protein, His Tag (MALS verified) \\
\hline \multirow{2}{*}{$\begin{array}{l}\text { Nucleocap } \\
\text { sid protein }\end{array}$} & SPN-S52H5 & SARS & HEK293 & SARS S protein (R667A), His Tag \\
\hline & NUN-V52H3 & $\mathrm{HCoV}-\mathrm{OC} 43$ & HEK293 & HCoV-OC43 Nucleocapsid protein, His Tag \\
\hline \multirow{5}{*}{ S1 protein } & $\mathrm{S} 1 \mathrm{~N}-\mathrm{C} 52 \mathrm{H} 3$ & SARS-CoV-2 & HEK293 & SARS-CoV-2 (COVID-19) S1 protein, His Tag \\
\hline & S1N-S52H5 & SARS & HEK293 & SARS S1 protein, His Tag (MALS verified) \\
\hline & S1N-C5256 & SARS-CoV-2 & HEK293 & SARS-CoV-2 (COVID-19) S1 protein (D614G), His Tag \\
\hline & S1N-C5257 & SARS-CoV-2 & HEK293 & SARS-CoV-2 (COVID-19) S1 protein, Mouse IgG2a Fc Tag \\
\hline & $\mathrm{S} 1 \mathrm{~N}-\mathrm{C} 52 \mathrm{H} 4$ & SARS-CoV-2 & HEK293 & SARS-CoV-2 (COVID-19) S1 protein, His Tag (MALS verified) \\
\hline \multirow{8}{*}{$\begin{array}{l}\mathrm{S} 2 \text { protein } \\
\mathrm{S} \text { protein } \\
\mathrm{RBD}\end{array}$} & $\mathrm{S} 2 \mathrm{~N}-\mathrm{C} 52 \mathrm{H} 5$ & SARS-CoV-2 & HEK293 & SARS-CoV-2 (COVID-19) S2 protein, His Tag \\
\hline & SPD-C82E9 & SARS-CoV-2 & HEK293 & Biotinylated SARS-CoV-2 (COVID-19) S protein RBD, \\
\hline & SPD-S52H5 & SARS-CoV-2 & HEK293 & SARS-CoV-2 (COVID-19) S protein RBD (N354D), His Tag \\
\hline & SPD-S52H6 & SARS & HEK293 & SARS S protein RBD, His Tag (MALS verified) \\
\hline & SPD-C52H3 & SARS-CoV-2 & HEK293 & SARS-CoV-2 (COVID-19) S protein RBD, His Tag \\
\hline & SPD-C5259 & SARS-CoV-2 & HEK293 & SARS-CoV-2 (COVID-19) S protein RBD, Mouse IgG2a Fc Tag \\
\hline & SPD-S52H4 & SARS-CoV-2 & HEK293 & SARS-CoV-2 (COVID-19) S protein RBD (V367F), His Tag \\
\hline & SPD-C52H4 & SARS-CoV-2 & HEK293 & SARS-CoV-2 (COVID-19) S protein RBD (G476S), His Tag \\
\hline
\end{tabular}




\begin{tabular}{l|l|l|l|l}
\hline \multirow{4}{*}{ Molecule } & Cat. No. & Species & Host & Product Description \\
\cline { 2 - 5 } & SPD-S52H7 & SARS-CoV-2 & HEK293 & SARS-CoV-2 (COVID-19) S protein RBD (W436R), His Tag \\
\cline { 2 - 5 } & SPD-S52H8 & SARS-CoV-2 & HEK293 & SARS-CoV-2 (COVID-19) S protein RBD (R408I), His Tag \\
\cline { 2 - 5 } & SPD-S52H3 & SARS-CoV-2 & HEK293 & SARS-CoV-2 (COVID-19) S protein RBD (N354D, D364Y) \\
\hline \multirow{2}{*}{ S1 protein } & SPD-C52H5 & SARS-CoV-2 & HEK293 & SARS-CoV-2 (COVID-19) S protein RBD (V483A), His Tag \\
\hline \multirow{2}{*}{ S protein } & SPN-C52H4 & SARS-CoV-2 & HEK293 & SARS-CoV-2 (COVID-19) S1 protein CTD, His Tag \\
\cline { 2 - 5 } & SPN-C52H8 & SARS-CoV-2 & HEK293 & SARS-CoV-2 (COVID-19) S protein (R683A, R685A) \\
\hline \multirow{2}{*}{ Papain } & PAE-C5148 & SARS-CoV-2 & E.coli & $\begin{array}{l}\text { SARS-CoV-2 (COVID-19) Papain-like Protease Protein, His } \\
\text { Tag }\end{array}$ \\
\hline \multirow{2}{*}{$\begin{array}{l}\text { Nucleocap } \\
\text { sid protein }\end{array}$} & ENN-C5128 & SARS-CoV-2 & E.coli & SARS-CoV-2 (COVID-19) Envelope protein, His Tag \\
\cline { 2 - 5 } & NUN-C51H9 & SARS-CoV-2 & E.coli & SARS-CoV-2 (COVID-19) Nucleocapsid protein, His Tag \\
\cline { 2 - 5 } NSP16 & NUN-C81Q6 & SARS-CoV-2 & HEK293 & SARS-CoV-2 (COVID-19) Nucleocapsid protein, His Tag \\
\hline NSP7 & NS0-C51W3 & SARS-CoV-2 & E.coli & $\begin{array}{l}\text { SARS-CoV-2 (COVID-19) NSP16\&NSP10 Heterodimer } \\
\text { Protein }\end{array}$ \\
\hline \multirow{2}{*}{ S1 protein } & NS8-C5125 & SARS-CoV-2 & E.coli & SARS-CoV-2 (COVID-19) NSP7\&NSP8 Protein, His Tag \\
\cline { 2 - 5 } & SIN-V52H3 & HCoV-NL63 & HEK293 & HCoV-NL63 S1 protein, His Tag \\
\cline { 2 - 5 } & SIN-V52H6 & HCoV-OC43 & HEK293 & HCoV-OC43 S1 protein, His Tag \\
\hline NSP1 & NS1-C51H7 & SARS-CoV-2 & E.coli & SARS-CoV-2 (COVID-19) NSP1 Protein, His Tag \\
\hline NSP7 & NS7-C51H6 & SARS-CoV-2 & E.coli & SARS-CoV-2 (COVID-19) NSP7 Protein, His Tag
\end{tabular}

In figure. 5, several graph inhibition of Sars-CoV-2 Spike RBD:ACE2 interaction by suitable anti-Sars-Cov-2 neutralizing antibody has been drawn for several mutated versions.

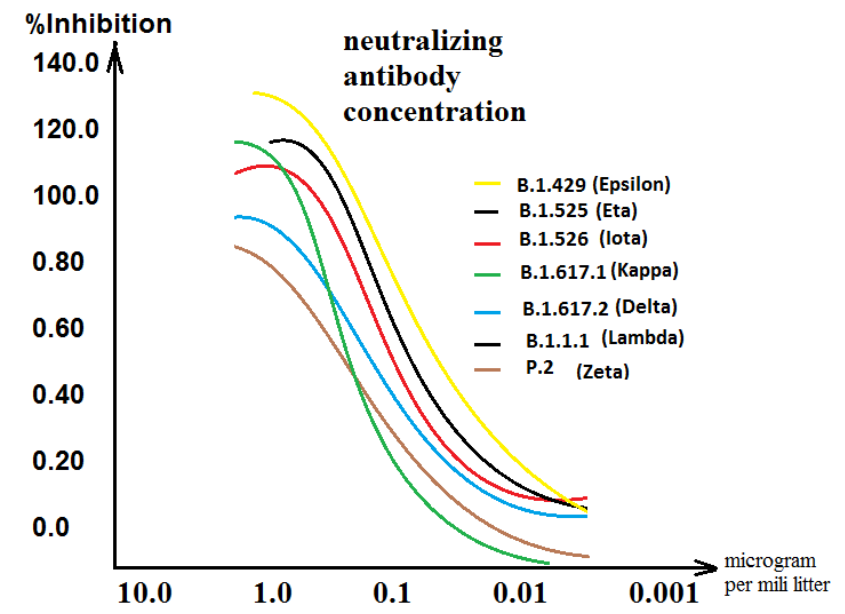

Figure 5. ACE2 interaction by the suitable anti-Sars-Cov-2 neutralizing antibody.

Via docking investigation, we analyzed on geometric shape complementarity score. A higher score indicates a higher binding affinity. The outcome of the results is based on the docking scores and interaction at the RBD regions. Protein-protein and antibody-protein interactions were visualized by VMD software. Molecular interactions of antibody and ACE2 receptors with RBD variants (Table 3) were performed by antibody script under antibody loop numbering. We analyzed interactions between RBD variants and ACE2 receptors. Moreover, we also can analyze the interactions between antibody and RBD variants. A high docking score signifies high binding affinity, and a low docking score signifies low binding affinity (figure $6)$.

Acquisition of glycan-binding domains and fusion thereof to the ancestral S protein may have resulted in a great extension of the $\mathrm{CoV}$ host range and may have caused an increase in $\mathrm{CoV}$ diversity. 


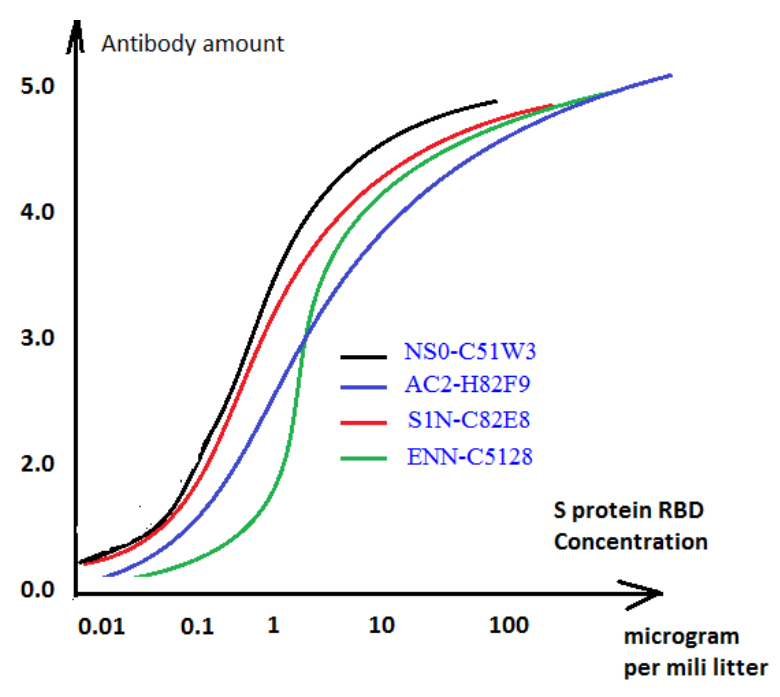

Figure 6. Detection of Spike RBD variants.

\subsection{Involvement of Viroporins.}

Viroporin, or virus-encoded protein that mediates ion channel activity, has a crucial function in infection. It is specified via its hydrophobicity and its ability to diffusion inside membranes through oligomerization. These viruses consist of several multifunctional proteins from various viral groups that are predominately concentrated in RNA viruses. SARS-CoVs and various CoVs encode several viroporins, such as $\mathrm{E}$ protein, with extra viroporins encoded by accessory genes. The E proteins are refuged via some CoVs, including HCoV-229E, SARSCoVs, MERS-CoVs, MHV, and IBV, and that they display vital functions viroporins [60-100].

Several important questions have to be discussed to be addressed: First; why does the number of accessory genes vary among CoVs from different genera, including $\alpha-\mathrm{CoV}, \beta-\mathrm{CoV}$, $\gamma-\mathrm{CoV}$, and $\delta-\mathrm{CoV}$, and even among the same $\mathrm{CoV}$ genus. Second, why does an increase or decrease in the number of accessory genes from several CoVs contribute to the improved adaptability of CoVs to a new host or cross-species transmission? Third, as CoVs employ diverse translational strategies that are not yet fully understood, do CoVs encode other unknown accessory proteins? Forth, how do these genes derive in broad host ranges of CoVs, such as SARS-CoV-2 and PDCoV. Fifth, what viral proteins interact with an accessory? Proteins. Sixth, do interactions occur among different accessory proteins from various CoVs with the same target organs, such as PDCoV, PEDV, and TGEV, resulting in more serious coinfections? AND finally, why delta variant of covid-19 is a concern compared with other variants. The answers to these questions will deepen our understanding of the function of accessory proteins in $\mathrm{CoVs}$ and facilitate the formulation of anti-viral strategies and the development of effective vaccines. The result showed that several compounds could bind finely to the target receptors at the expected sides'. Several Gibbs energy of binding energies calculated by the docking scores among those of the compounds and those of the receptors. Interestingly, we exhibited; these compounds accomplish superior binding affinities to each receptor.

\section{Conclusions}

Coronavirusare extensively involved in the host immune response; therefore, studies on the functions of related proteins have become a major point in the $\mathrm{CoV}$ area. Accessory proteins often function in combination rather than individually. They share the various 
processes of the viral replication cycle and modulate host immunity, which consists of autophagy, apoptosis, innate immunity, and total stress response. Many different lineages are not variants of concern or interest. These are grouped as 'Other' on this chart. As the proportions of concern variants and interest variants increase, the proportion of other lineages will decrease. Variants of concern and variants of interest include: B.1.1.7 (alpha) , B.1.351 (beta) , P.1 (gamma), B.1.617.2 (delta), B.1.427 (epsilon), B.1.429 (epsilon), B.1.526 (iota), B.1.525 (eta), B.1.617.1 (kappa) and B.1.617.3. The $\lambda$-SARS-CoV-2 variant, also known as C.37, is a variant of SARS-CoV-2 that was first detected in Peru ( August 2020) and was also named $\lambda$-variant by the World Health Organization (WHO) On June 14, 2021. However, the molecular mechanisms applied via accessory proteins remain largely unclear information, especially in the context of infection. In summary, future researches of accessory proteins from diverse perspectives will facilitate a deeper understanding of the biology of these important viruses and will aid our ability to treat and prevent infections. Via docking investigation, it is possible to analyze Protein-protein and antibody-protein interactions that also can be visualized by VMD or Rasmol software.

\section{Funding}

This research received no external funding.

\section{Acknowledgments}

The authors thank Kastamonu University and Islamic Azad university for providing computer and software equipment.

\section{Conflicts of Interest}

The authors declare no conflict of interest.

\section{References}

1. Liu, Z.; VanBlargan, L.A.; Bloyet, L.-M.; Rothlauf, P.W.; Chen, R.E.; Stumpf, S.; Zhao, H.; Errico, J.M.; Theel, E.S.; Liebeskind, M.J.; Alford, B.; Buchser, W.J.; Ellebedy, A.H.; Fremont, D.H.; Diamond, M.S.; Whelan, S.P.J. Identification of SARS-CoV-2 spike mutations that attenuate monoclonal and serum antibody neutralization. Cell Host \& Microbe 2021, 29, 477-488.e474, https://doi.org/10.1016/j.chom.2021.01.014.

2. Abu-Raddad, L. J.; Chemaitelly, H.; Ayoub, H. H.; Yassine, H. M.; Benslimane, F. M.; Al Khatib, H. A.; Tang, P.; Hasan, M. R.; Coyle, P.; AlMukdad, S.; Al Kanaani, Z.; Al Kuwari, E.; Jeremijenko, A.; Kaleeckal, A. H.; Latif, A. N.; Shaik, R. M.; Abdul Rahim, H. F.; Nasrallah, G. K.; Al Kuwari, M. G.; Butt, A. A.; Al Romaihi, H. E.; Al-Thani, M. H.; Al Khal, A.; Bertollini, R., Severity, criticality, and fatality of the SARSCoV-2 Beta variant. medRxiv 2021, 2021.08.02.21261465. http://medrxiv.org /content/ early/ 2021/08/04/2021.08.02.21261465.abstract

3. Wink, P.L.; Volpato, F.; de Lima-Morales, D.; Paiva, R.M.; Willig, J.B.; Bock, H.; de Paris, F.; Luís Barth, A. RT-PCR half reaction optimization for the detection of SARS-CoV-2. medRxiv 2021, 2021, https://doi.org/10.1101/2021.05.19.21257470.

4. Romero, P.E.; Dávila-Barclay, A.; Gonzáles, L.; Salvatierra, G.; Cuicapuza, D.; Solis, L.; Marcos, P.; Huancachoque, J.; Carhuaricra, D.; Rosadio, R.C. 37: Novel lineage expanding in Peru and Chile, with a convergent deletion in the ORF1a gene $(\Delta 3675-3677)$ and a novel deletion in the Spike gene $(\Delta 246-252$, G75V, T76I, L452Q, F490S, T859N). April 2021.

5. Peru Ministerio de Salud: Instituto Nacional de Salud. INS confirma presencia de variante C-37 del coronavirus en Perú, 25 Mayo 2021. https://web.ins.gob.pe/index.php/es/prensa/noticia/minsa-insconfirmapresencia-de-variante-c-37-del-coronavirus-en-peru Published 2021. Published 2021. Accessed June 15, 2021.

6. Argentina.gob.ar. Vigilancia de variantes de SARS-CoV-2 en CABA, Provincia de Buenos Aires, Córdoba, Entre Ríos, Neuquén y Santa Fe. Available on-line at: https://www.argentina.gob.ar/noticias/vigilancia-de- 
variantes-de-sars-cov-2-en-caba-provincia-de-buenos-aires-cordoba-entre-rios Published 2021. Accessed June 15, 2021.

7. Latif, AA.; Mullen, J.L; Alkuzweny, M.; Tsueng, G.; Cano, M.; Haag, E.; Zhou, J.; Zeller, M.; Hufbauer, E.; Matteson, N.; Wu, C.; Andersen, K.G.; Su, A.I.; Gangavarapu, K.; Hughes, L.D. Chile Mutation Report. https://outbreak.info/location-reports?loc=CHL\&pango=C.37 Published 2021. Accessed June 15, 2021.

8. Robertson, S. Lambda lineage of SARS-CoV-2 has potential to become variant of concern. news-medical.net. Retrieved 2021-07-05. The Lambda variant also contained a novel deletion ( $\Delta 246-252)$ and multiple nonsynonymous mutations (G75V, T76I, L452Q, F490S, D614G, and T859N) in the gene that encodes the viral spike protein.

9. Hemann, E.A.; Gale, M.J.; Savan, R. Interferon Lambda Genetics and Biology in Regulation of Viral Control. Front. Immunol. 2017, 8, https://dx.doi.org/10.3389\%2Ffimmu.2017.01707.

10. Prokunina-Olsson, L.; Alphonse, N.; Dickenson, R.E.; Durbin, J.E.; Glenn, J.S.; Hartmann, R.; Kotenko, S.V.; Lazear, H.M.; ','O’Brien, T.R.; Odendall, C.; Onabajo, O.O.; Piontkivska, H.; Santer, D.M.; Reich, N.C.; Wack, A.; Zanoni, I. COVID-19 and emerging viral infections: The case for interferon lambda. The Journal of experimental medicine 2020, 217, https://doi.org/10.1084/jem.20200653.

11. Jang, Y.; Shin, H.; Lee, M.K.; Kwon, O.S.; Shin, J.S.; Kim, Y.I.; Kim, C.W.; Lee, H.R.; Kim, M. Anti-viral activity of lambda-carrageenan against influenza viruses and severe acute respiratory syndrome coronavirus 2. Sci Rep 2021, 11, https://doi.org/10.1038/s41598-020-80896-9.

12. Chen, H.; Yan, X.; Lin, J.; Wang, F.; Xu, W. Depolymerized products of lambda-carrageenan as a potent angiogenesis inhibitor. J Agric Food Chem 2007, 55, 6910-6917, https://doi.org/10.1021/jf070183+.

13. Andreakos, E.; Tsiodras, S. COVID-19: lambda interferon against viral load and hyperinflammation. EMBO molecular medicine 2020, 12, https://doi.org/10.15252/emmm.202012465.

14. Hanke, L.; Vidakovics Perez, L.; Sheward, D.J.; Das, H.; Schulte, T.; Moliner-Morro, A.; Corcoran, M.; Achour, A.; Karlsson Hedestam, G.B.; Hallberg, B.M.; et al. An alpaca nanobody neutralizes SARS-CoV-2 by blocking receptor interaction. Nat.Commun. 2020, 11, 4420.

15. Woo, P.C.Y.; Lau, S.K.P.; Lam, C.S.F.; Lau, C.C.Y.; Tsang, A.K.L.; Lau, J.H.N.; Bai, R.; Teng, J.L.L.; Tsang, C.C.C.; Wang, M.; Zheng, B.-J.; Chan, K.-H.; Yuen, K.-Y. Discovery of seven novel Mammalian and avian coronaviruses in the genus deltacoronavirus supports bat coronaviruses as the gene source of alphacoronavirus and betacoronavirus and avian coronaviruses as the gene source of gammacoronavirus and deltacoronavirus. Journal of virology 2012, 86, 3995-4008, https://doi.org/10.1128/JVI.06540-11.

16. Zhang, J. Porcine deltacoronavirus: Overview of infection dynamics, diagnostic methods, prevalence and genetic evolution. Virus Res 2016, 226, 71-84, https://doi.org/10.1016/j.virusres.2016.05.028.

17. Wille, M.; Holmes, E.C. Wild birds as reservoirs for diverse and abundant gamma- and deltacoronaviruses. FEMS Microbiol Rev 2020, 44, 631-644, https://doi.org/10.1093/femsre/fuaa026.

18. Jung, K.; Hu, H.; Saif, L.J. Calves are susceptible to infection with the newly emerged porcine deltacoronavirus, but not with the swine enteric alphacoronavirus, porcine epidemic diarrhea virus. Archives of virology 2017, 162, 2357-2362, https://doi.org/10.1007/s00705-017-3351-z.

19. Liang, Q.; Zhang, H.; Li, B.; Ding, Q.; Wang, Y.; Gao, W.; Guo, D.; Wei, Z.; Hu, H. Susceptibility of Chickens to Porcine Deltacoronavirus Infection. Viruses 2019, 11, https://dx.doi.org/10.3390\%2Fv11060573.

20. Boley, P.A.; Alhamo, M.A.; Lossie, G.; Yadav, K.K.; Vasquez-Lee, M.; Saif, L.J.; Kenney, S.P.; Boley, P. Porcine Deltacoronavirus Infection and Transmission in Poultry, United States1. Emerg. Infect. Dis. 2020, 26, 255-265, https://doi.org/10.3201/eid2602.190346.

21. Jolly, B.; Rophina, M.; Shamnath, A.; Imran, M.; Bhoyar, R.C.; Divakar, M.K.; Rani, P.R.; Ranjan, G.; Sehgal, P.; Chandrasekhar, P.; et al. Genetic epidemiology of variants associated with immune escape from global SARS-CoV-2 genomes. Biorxiv Prepr. Serv. Biol. 2020.

22. Fang, P.; Fang, L.; Hong, Y.; Liu, X.; Dong, N.; Ma, P.; Bi, J.; Wang, D.; Xiao, S. Discovery of a novel accessory protein NS7a encoded by porcine deltacoronavirus. The Journal of general virology 2017, 98, 173178, https://doi.org/10.1099/jgv.0.000690.

23. Fang, P.; Fang, L.; Liu, X.; Hong, Y.; Wang, Y.; Dong, N.; Ma, P.; Bi, J.; Wang, D.; Xiao, S. Identification and subcellular localization of porcine deltacoronavirus accessory protein NS6. Virology 2016, 499, 170177, https://doi.org/10.1016/j.virol.2016.09.015.

24. Luo, J.; Fang, L.; Dong, N.; Fang, P.; . Ding, Z.; Wang, D.; Chen, H.; Xiao, S. Porcine deltacoronavirus (PDCoV) infection suppresses RIG-I-mediated interferon-beta production. Virology 2016, 495, 10-17, https://doi.org/10.1016/j.virol.2016.04.025.

25. Fang, P.; Fang, L.; Ren, J.; Hong, Y.; Liu, X.; Zhao, Y.; Wang, D.; Peng, G.; Xiao, S. Porcine Deltacoronavirus Accessory Protein NS6 Antagonizes Interferon Beta Production by Interfering with the Binding of RIG-I/MDA5 to Double-Stranded RNA. J. Virol. 2018, 92, https://doi.org/10.1128/jvi.00712-18.

26. Fang, P.; Fang, L.; Xia, S.; Ren, J.; Zhang, J.; Bai, D.; Zhou, Y.; Peng, G.; Zhao, S.; Xiao, S. Porcine Deltacoronavirus Accessory Protein NS7a Antagonizes IFN-beta Production by Competing With TRAF3 and IRF3 for Binding to IKKepsilon. Front. Cell. Infect. Microbiol. 2020, 10, https://dx.doi.org/10.3389\%2Ffcimb.2020.00257. 
27. Jung, K.; Miyazaki, A.; Hu, H.; Saif, L.J. Susceptibility of porcine IPEC-J2 intestinal epithelial cells to infection with porcine deltacoronavirus (PDCoV) and serum cytokine responses of gnotobiotic pigs to acute infection with IPEC-J2 cell culture-passaged PDCoV. Vet. Microbiol. 2018, 221, 49-58, https://doi.org/10.1016/j.vetmic.2018.05.019.

28. Lee, Y.J.; Lee, C. Porcine deltacoronavirus induces caspase-dependent apoptosis through activation of the cytochrome c -mediated intrinsic mitochondrial pathway. Virus Res. 2018, 253, 112-123, https://doi.org/10.1016/j.virusres.2018.06.008.

29. Jung, K.; Hu, H.; Saif, L.J. Porcine deltacoronavirus induces apoptosis in swine testicular and LLC porcine kidney cell lines in vitro but not in infected intestinal enterocytes in vivo. Vet. Microbiol. 2016, 182, 57-63, https://doi.org/10.1016/j.vetmic.2015.10.022.

30. Qin, P.; Du, E.-Z.; Luo, W.-T.; Yang, Y.-L.; Zhang, Y.-Q.; Wang, B.; Huang, Y.-W. Characteristics of the Life Cycle of Porcine Deltacoronavirus (PDCoV) In Vitro: Replication Kinetics, Cellular Ultrastructure and Virion Morphology, and Evidence of Inducing Autophagy. Viruses 2019, 11, https://dx.doi.org/10.3390\%2Fv11050455.

31. Bai, D.; Fang, L.; Xia, S.; Ke, W.; Wang, J.; Wu, X.; Fang, P.; Xiao, S. Porcine deltacoronavirus (PDCoV) modulates calcium influx to favor viral replication. Virology 2020, 539, 38-48, https://doi.org/10.1016/j.virol.2019.10.011.

32. Zhang, M.; Li, W.; Zhou, P.; Liu, D.; Luo, R.; Jongkaewwattana, A.; He, Q. Genetic manipulation of porcine deltacoronavirus reveals insights into NS6 and NS7 functions: A novel strategy for vaccine design. Emerg. Microbes Infect. 2019, 9, 20-31, https://dx.doi.org/10.1080\%2F22221751.2019.1701391.

33. McCallum, M.; Bassi, J.; De Marco, A.; Chen, A.; Walls, A.C.; Di Iulio, J.; Tortorici, M.A.; Navarro, M.J.; Silacci-Fregni, C.; Saliba, C.; Sprouse, K.R.; Agostini, M.; Pinto, D.; Culap, K.; Bianchi, S.; Jaconi, S.; Cameroni, E.; Bowen, J.E.; Tilles, S.W.; Pizzuto, M.S.; Guastalla, S.B.; Bona, G.; Pellanda, A.F.; Garzoni, C.; Van Voorhis, W.C.; Rosen, L.E.; Snell, G.; Telenti, A.; Virgin, H.W.; Piccoli, L.; Corti, D.; Veesler, D, SARS-CoV-2 immune evasion by the B.1.427/B.1.429 variant of concern. Science 2021, 373, 648-654, https://doi.org/10.1126/science.abi7994.

34. Rambaut, A.; Holmes, E.C.; O’Toole, Á.; Hill, V.; McCrone, J.T.; Ruis, C.; du Plessis, L.; Pybus, O.G. A dynamic nomenclature proposal for SARS-CoV-2 lineages to assist genomic epidemiology. Nature Microbiology 2020, 5, 1403-1407, https://doi.org/10.1038/s41564-020-0770-5.

35. McCallum, M.; Bassi, J.; De Marco, A.; Chen, A.; Walls, A.C.; Di Iulio, J.; Tortorici, M.A.; Navarro, M.J.; Silacci-Fregni, C.; Saliba, C.; Sprouse, K.R.; Agostini, M.; Pinto, D.; Culap, K.; Bianchi, S.; Jaconi, S.; Cameroni, E.; Bowen, J.E.; Tilles, S.W.; Pizzuto, M.S.; Guastalla, S.B.; Bona, G.; Pellanda, A.F.; Garzoni, C.; Van Voorhis, W.C.; Rosen, L.E.; Snell, G.; Telenti, A.; Virgin, H.W.; Piccoli, L.; Corti, D.; Veesler, D. SARS-CoV-2 immune evasion by the B.1.427/B.1.429 variant of concern. Science (New York, N.Y.) 2021, 373, 648-654, https://doi.org/10.1126/science.abi7994.

36. Tchesnokova, V.; Kulakesara, H.; Larson, L.; Bowers, V.; Rechkina, E.; Kisiela, D.; Sledneva, Y.; Choudhury, D.; Maslova, I.; Deng, K.; Kutumbaka, K.; Geng, H.; Fowler, C.; Greene, D.; Ralston, J.; Samadpour, M.; Sokurenko, E. Acquisition of the L452R mutation in the ACE2-binding interface of Spike protein triggers recent massive expansion of SARS-Cov-2 variants. bioRxiv 2021, https://doi.org/10.1101/2021.02.22.432189.

37. Gobeil, S.M.; Janowska, K.; McDowell, S.; Mansouri, K.; Parks, R.; Stalls, V.; Kopp, M.F.; Manne, K.; Saunders, K.; Edwards, R.J.; Haynes, B.F.; Henderson, R.C.; Acharya, P. Effect of natural mutations of SARS-CoV-2 on spike structure, conformation and antigenicity. bioRxiv 2021, https://doi.org/10.1101/2021.03.11.435037.

38. Burgess, M. Spike protein mutations in SARS-CoV-2 variants help resist antibody neutralization. NewsMedical. Retrieved on September 02, 2021, https://www.news-medical.net/news/20210311/Spike-proteinmutations-in-SARS-CoV-2-variants-help-resist-antibody-neutralization.aspx.

39. Yang, J.M.; Chen, C.C. GEMDOCK: A generic evolutionary method for molecular docking. Proteins: Structure, Function, and Bioinformatics 2004, 55, 288-304.

40. Yang, J.M. Development and evaluation of a generic evolutionary method for protein-ligand docking. $J$ Comput Chem 2004, 25, 843-857, https://doi.org/10.1002/jcc.20013.

41. Yang, J.M.; Shen, T.W. A pharmacophore-based evolutionary approach for screening selective estrogen receptor modulators. Proteins 2005, 59, 205-220, https://doi.org/10.1002/prot.20387.

42. Monajjemi, M. Cell membrane causes the lipid bilayers to behave as variable capacitors: A resonance with self-induction of helical proteins. Biophysical Chemistry 2015, 207, 114-127, https://doi.org/10.1016/j.bpc.2015.10.003.

43. Monajjemi, M. Liquid-phase exfoliation (LPE) of graphite towards graphene: An ab initio study. Journal of Molecular Liquids, 2017, 230, 461-472, https://doi.org/10.1016/j.molliq.2017.01.044.

44. Monajjemi, M.; Naderi, F.; Mollaamin, F.; Khaleghian, M. Drug design outlook by calculation of second virial coefficient as a nano study. Journal of the Mexican Chemical Society 2012, 56, 207-211, https://doi.org/10.29356/jmcs.v56i2.323. 
45. Monajjemi, M.; Bagheri, S.; Moosavi, M.S. Symmetry breaking of B2N(-,0,+): An aspect of the electric potential and atomic charges. Molecules 2015, 20, 21636-21657, https://doi.org/10.3390/molecules201219769.

46. Monajjemi, M.; Mohammadian, N.T. S-NICS: An aromaticity criterion for nano molecules. Journal of Computational and Theoretical Nanoscience 2015, 12, 4895-4914, https://doi.org/10.1166/jctn.2015.4458.

47. Monajjemi, M.; Ketabi, S.; Hashemian, Z.M.; Amiri, A. Simulation of DNA bases in water: Comparison of the Monte Carlo algorithm with molecular mechanics force fields. Biochemistry (Moscow) 2006, 71, 1-8, https://doi.org/10.1134/s0006297906130013.

48. Monajjemi, M.; Lee, V.S.; Khaleghian, M.; Honarparvar, B.; Mollaamin, F. Theoretical Description of Electromagnetic Nonbonded Interactions of Radical, Cationic, and Anionic NH2BHNBHNH2 Inside of the B18N18 Nanoring. J. Phys. Chem C 2010, 114, 15315-15330, https://doi.org/10.1021/jp104274z.

49. Monajjemi, M.; Boggs, J.E. A New Generation of BnNn Rings as a Supplement to Boron Nitride Tubes and Cages. J. Phys. Chem. A 2013, 117, 1670-1684, http://dx.doi.org/10.1021/jp312073q.

50. Monajjemi, M. Non bonded interaction between BnNn (stator) and BN B (rotor) systems: A quantum rotation in IR region. Chemical Physics 2013, 425, 29-45, https://doi.org/10.1016/j.chemphys.2013.07.014.

51. Monajjemi, M.; Robert, W.J.; Boggs, J.E. NMR contour maps as a new parameter of "'carboxyl's OH groups in amino acids recognition: A reason of tRNA-amino acid conjugation. Chemical Physics 2014, 433, 1-11, https://doi.org/10.1016/j.chemphys.2014.01.017.

52. Monajjemi, M. Quantum investigation of non-bonded interaction between the B15N15 ring and BH2NBH2 (radical, cation, and anion) systems: a nano molecularmotor. Struct Chem 2012, 23, 551-580, http://dx.doi.org/10.1007/s11224-011-9895-8.

53. Monajjemi, M. Metal-doped graphene layers composed with boron nitride-graphene as an insulator: a nanocapacitor. Journal of Molecular Modeling 2014, 20, https://doi.org/10.1007/s00894-014-2507-y.

54. Monajjemi, M.; Heshmat, M.; Haeri, H.H.; Kaveh, F. Theoretical study of vitamin properties from combined QM-MM methods: Comparison of chemical shifts and energy. Russian Journal of Physical Chemistry 2006, 80, 1061-1068, https://doi.org/10.1134/S0036024406070119.

55. Monajjemi, M.; Honaparvar, B.; Khalili Hadad, B.; Ilkhani, A.; Mollaamin, F. Thermo-Chemical Investigation and NBO Analysis of Some anxileotic as Nano- Drugs. African journal of pharmacy and pharmacology 2010, 4, 521-529.

56. Monajjemi, M.; Najafpour, J.; Mollaamin, F. (3,3)4 Armchair Carbon Nanotube in Connection with PNP and NPN Junctions: Ab Initio and DFT-Based Studies. Fullerenes, Nanotubes and Carbon Nanostructures 2013, 21, 213-232, https://doi.org/10.1080/1536383X.2011.597010.

57. Monajjemi, M.; Jafari Azan, M.; Mollaamin, F. Density Functional Theory Study on B30N20 Nanocage in Structural Properties and Thermochemical Outlook. Fullerenes, Nanotubes and Carbon Nanostructures 2013, 21, 503-515, https://doi.org/10.1080/1536383X.2011.629762.

58. Monajjemi, M.; Ghiasi, R.; Ketabi, S.; Passdar, H.; Mollaamin, F. A Theoretical Study of Metal-Stabilised Rare Tautomers Stability: N4 Metalated Cytosine (M=Be2+, Mg2+, Ca2+, $\mathrm{Sr} 2+$ and $\mathrm{Ba} 2+)$ in Gas Phase and Different. Journal of Chemical Research 2004, 1, 11-18, https://doi.org/10.3184/030823404323000648.

59. Monajjemi, M.; Baheri, H.; Mollaamin, F. A percolation model for carbon nanotube-polymer composites using the Mandelbrot-Given curve. Journal of Structural Chemistry 2011, 52, 54-59, https://doi.org/10.1134/S0022476611010070.

60. Li, R.; Pei, S.; Chen, B.; Song, Y.; Zhang, T.; Yang, W.; Shaman, J. Substantial undocumented infection facilitates the rapid dissemination of novel coronavirus (SARS-CoV-2). Science 2020, 368, 489-493, https://doi.org/10.1126/science.abb3221.

61. Jung, K.; Saif, L.J.; Wang, Q. Porcine epidemic diarrhea virus (PEDV): An update on etiology, transmission, pathogenesis, and prevention and control. Virus Res. 2020, 286, https://doi.org/10.1016/j.virusres.2020.198045.

62. Shi, J.; Wen, Z.; Zhong, G.; Yang, H.; Wang, C.; Huang, B.; Liu, R.; He, X.; Shuai, L.; Sun, Z.; Zhao, Y.; Liu, P.; Liang, L.; Cui, P.; Wang, J.; Zhang, X.; Guan, Y.; Tan, W.; Wu, G.; Chen, H.; Bu, Z. Susceptibility of ferrets, cats, dogs, and other domesticated animals to SARS-coronavirus 2. Science (New York, N.Y.) 2020, 368, 1016-1020, https://doi.org/10.1126/science.abb7015.

63. Yang, Y.-L.; Yu, J.-Q.; Huang, Y.-W. Swine enteric alphacoronavirus (swine acute diarrhea syndrome coronavirus): An update three years after its discovery. Virus Res. 2020, 285, https://dx.doi.org/10.1016\%2Fj.virusres.2020.198024.

64. Legnardi, M.; Tucciarone, C.M.; Franzo, G.; Cecchinato, M. Infectious Bronchitis Virus Evolution, Diagnosis and Control. Vet. Sci. 2020, 7, https://dx.doi.org/10.3390\%2Fvetsci7020079.

65. Lednicky, J.A.; Tagliamonte, M.S.; White, S.K.; Elbadry, M.A.; Alam, M.M.; Stephenson, C.J.; Bonny, T.S.; Loeb, J.C.; Telisma, T.; Chavannes, S.; Ostrov, D.A.; Mavian, C.; De Rochars, V.M.B.; Salemi, M.; Morris, J.G. Emergence of porcine delta-coronavirus pathogenic infections among children in Haiti through independent zoonoses and convergent evolution. medRxiv 2021, https://doi.org/10.1101/2021.03.19.21253391.

66. Michel, C.J.; Mayer, C.; Poch, O.; Thompson, J.D. Characterization of accessory genes in coronavirus genomes. Virol. J. 2020, 17, 1-13, https://doi.org/10.1186/s12985-020-01402-1. 
67. Blanco-Melo, D.; Nilsson-Payant, B.E.; Liu, W.C.; Uhl, S.; Hoagland, D.; Moller, R.; Jordan, T.X.; Oishi, K.; Panis, M.; Sachs, D.; et al. Imbalanced Host Response to SARS-CoV-2 Drives Development of COVID19. Cell 2020, 181, 1036-1045. [CrossRef]

68. Gordon, D.E.; Jang, G.M.; Bouhaddou, M.; Xu, J.; Obernier, K.; White, K.M.; O’Meara, M.J.; Rezelj, V.V.; Guo, J.Z.; Swaney, D.L.; Tummino, T.A.; Hüttenhain, R.; Kaake, R.M.; Richards, A.L.; Tutuncuoglu, B.; Foussard, H.; Batra, J.; Haas, K.; Modak, M.; Kim, M.; Haas, P.; Polacco, B.J.; Braberg, H.; Fabius, J.M.; Eckhardt, M.; Soucheray, M.; Bennett, M.J.; Cakir, M.; McGregor, M.J.; Li, Q.; Meyer, B.; Roesch, F.; Vallet, T.; Mac Kain, A.; Miorin, L.; Moreno, E.; Naing, Z.Z.C.; Zhou, Y.; Peng, S.; Shi, Y.; Zhang, Z.; Shen, W.; Kirby, I.T.; Melnyk, J.E.; Chorba, J.S.; Lou, K.; Dai, S.A.; Barrio-Hernandez, I.; Memon, D.; HernandezArmenta, C.; Lyu, J.; Mathy, C.J.P.; Perica, T.; Pilla, K.B.; Ganesan, S.J.; Saltzberg, D.J.; Rakesh, R.; Liu, X.; Rosenthal, S.B.; Calviello, L.; Venkataramanan, S.; Liboy-Lugo, J.; Lin, Y.; Huang, X.-P.; Liu, Y.; Wankowicz, S.A.; Bohn, M.; Safari, M.; Ugur, F.S.; Koh, C.; Savar, N.S.; Tran, Q.D.; Shengjuler, D.; Fletcher, S.J.; O’Neal, M.C.; Cai, Y.; Chang, J.C.J.; Broadhurst, D.J.; Klippsten, S.; Sharp, P.P.; Wenzell, N.A.; Kuzuoglu-Ozturk, D.; Wang, H.-Y.; Trenker, R.; Young, J.M.; Cavero, D.A.; Hiatt, J.; Roth, T.L.; Rathore, U.; Subramanian, A.; Noack, J.; Hubert, M.; Stroud, R.M.; Frankel, A.D.; Rosenberg, O.S.; Verba, K.A.; Agard, D.A.; Ott, M.; Emerman, M.; Jura, N.; von Zastrow, M.; Verdin, E.; Ashworth, A.; Schwartz, O.; d'Enfert, C.; Mukherjee, S.; Jacobson, M.; Malik, H.S.; Fujimori, D.G.; Ideker, T.; Craik, C.S.; Floor, S.N.; Fraser, J.S.; Gross, J.D.; Sali, A.; Roth, B.L.; Ruggero, D.; Taunton, J.; Kortemme, T.; Beltrao, P.; Vignuzzi, M.; García-Sastre, A.; Shokat, K.M.; Shoichet, B.K.; Krogan, N.J. A SARS-CoV-2 protein interaction map reveals targets for drug repurposing. Nature 2020, 583, 459-468, https://doi.org/10.1038/s41586-020-2286-9.

69. Wu, J.; Shi, Y.; Pan, X.; Wu, S.; Hou, R.; Zhang, Y.; Zhong, T.; Tang, H.; Du, W.; Wang, L.; Wo, J.; Mu, J.; Qiu, Y.; Yang, K.; Zhang, L.K.; Ye, B.C.; Qi, N. SARS-CoV-2 ORF9b inhibits RIG-I-MAVS anti-viral signaling by interrupting K63-linked ubiquitination of NEMO. Cell Rep 2021, 34, https://doi.org/10.1016/j.celrep.2021.108761.

70. Wong, L.R.; Ye, Z.W.; Lui, P.Y.; Zheng, X.; Yuan, S.; Zhu, L.; Fung, S.Y.; Yuen, K.S.; Siu, K.L.; Yeung, M.L.; Cai, Z.; Woo, P.C.; Yuen, K.Y.; Chan, C.P.; Jin, D.Y. Middle East Respiratory Syndrome Coronavirus ORF8b Accessory Protein Suppresses Type I IFN Expression by Impeding HSP70-Dependent Activation of IRF3 Kinase IKKe. Journal of immunology (Baltimore, Md.: 1950) 2020, 205, 1564-1579, https://doi.org/10.4049/jimmunol.1901489.

71. Li, J.Y.; Liao, C.H.; Wang, Q.; Tan, Y.J.; Luo, R.; Qiu, Y.; Ge, X.Y. The ORF6, ORF8 and nucleocapsid proteins of SARS-CoV-2 inhibit type I interferon signaling pathway. Virus Res. 2020, 286, https://doi.org/10.1016/j.virusres.2020.198074.

72. Lei, X.; Dong, X.; Ma, R.; Wang, W.; Xiao, X.; Tian, Z.; Wang, C.; Wang, Y.; Li, L.; Ren, L.; Guo, F.; Zhao, Z.; Zhou, Z.; Xiang, Z.; Wang, J. Activation and evasion of type I interferon responses by SARS-CoV-2. Nature Communications 2020, 11, https://doi.org/10.1038/s41467-020-17665-9.

73. Konno, Y.; Kimura, I.; Uriu, K.; Fukushi, M.; Irie, T.; Koyanagi, Y.; Sauter, D.; Gifford, R.J.; Nakagawa, S.; Sato, K. SARS-CoV-2 ORF3b Is a Potent Interferon Antagonist Whose Activity Is Increased by a Naturally Occurring Elongation Variant. Cell Reports 2020, 32, 108-185, https://doi.org/10.1016/j.celrep.2020.108185.

74. Flower, T.G.; Buffalo, C.Z.; Hooy, R.M.; Allaire, M.; Ren, X.; Hurley, J.H. Structure of SARS-CoV-2 ORF8, a rapidly evolving immune evasion protein. Proc. Natl. Acad. Sci. USA 2021, 118, https://doi.org/10.1073/pnas.2021785118.

75. Miorin, L.; Kehrer, T.; Sanchez-Aparicio, M.T.; Zhang, K.; Cohen, P.; Patel, R.S.; Cupic, A.; Makio, T.; Mei, M.; Moreno, E.; Danziger, O.; White, K.M.; Rathnasinghe, R.; Uccellini, M.; Gao, S.; Aydillo, T.; Mena, I.; Yin, X.; Martin-Sancho, L.; Krogan, N.J.; Chanda, S.K.; Schotsaert, M.; Wozniak, R.W.; Ren, Y.; Rosenberg, B.R.; Fontoura, B.M.A.; García-Sastre, A. SARS-CoV-2 Orf6 hijacks Nup98 to block STAT nuclear import and antagonize interferon signaling. Proc. Nat. Acad. Sci. USA 2020, 117, 28344-28354, https://doi.org/10.1073/pnas.2016650117.

76. Shang, J.; Han, N.; Chen, Z.; Peng, Y.; Li, L.; Zhou, H.; Ji, C.; Meng, J.; Jiang, T.; Wu, A. Compositional diversity and evolutionary pattern of coronavirus accessory proteins. Briefings Bioinform. 2021, 22, 12671278, https://doi.org/10.1093/bib/bbaa262.

77. Zhou, F.; Yu, T.; Du, R.; Fan, G.; Liu, Y.; Liu, Z.; Xiang, J.; Wang, Y.; Song, B.; Gu, X.; Guan, L.; Wei, Y.; Li, H.; Wu, X.; Xu, J.; Tu, S.; Zhang, Y.; Chen, H.; Cao, B. Clinical course and risk factors for mortality of adult inpatients with COVID-19 in Wuhan, China: a retrospective cohort study. Lancet (London, England) 2020, 395, 1054-1062, https://doi.org/10.1016/s0140-6736(20)30566-3.

78. Freeman, T.L.; Swartz, T.H. Targeting the NLRP3 Inflammasome in Severe COVID-19. Front. Immunol. 2020, 11, https://doi.org/10.3389/fimmu.2020.01518.

79. Sendler, M.; van den Brandt, C.; Glaubitz, J.; Wilden, A.; Golchert, J.; Weiss, F.U.; Homuth, G.; De Freitas Chama, L.L.; Mishra, N.; Mahajan, U.M.; Bossaller, L.; Völker, U.; Bröker, B.M.; Mayerle, J.; Lerch, M.M. NLRP3 Inflammasome Regulates Development of Systemic Inflammatory Response and Compensatory Anti-Inflammatory Response Syndromes in Mice With Acute Pancreatitis. Gastroenterology 2020, 158, 253269.e214, https://doi.org/10.1053/j.gastro.2019.09.040. 
80. Paniri, A.; Akhavan-Niaki, H. Emerging role of IL-6 and NLRP3 inflammasome as potential therapeutic targets to combat COVID-19: Role of lncRNAs in cytokine storm modulation. Life Sci. 2020, 257, https://dx.doi.org/10.1016\%2Fj.lfs.2020.118114.

81. Kaewborisuth, C.; Koonpaew, S.; Srisutthisamphan, K.; Viriyakitkosol, R.; Jaru-Ampornpan, P.; Jongkaewwattana, A. PEDV ORF3 Independently Regulates IkappaB Kinase beta-Mediated NF-kappaB and IFN-beta Promoter Activities. Pathogens 2020, 9, https://doi.org/10.3390/pathogens9050376.

82. Wu, Z.; Cheng, L.; Xu, J.; Li, P.; Li, X.; Zou, D.; Zhang, Y.; Wang, X.; Wu, X.; Shen, Y.; Li, Y.; Yao, L.; Guo, D.; Li, L.; Xiao, L.; Song, B.; Ma, J.; Liu, X.; Xu, S.; Xu, X.; Zhang, H.; Zheng, L.; Cao, H. The accessory protein ORF3 of porcine epidemic diarrhea virus inhibits cellular interleukin-6 and interleukin-8 productions by blocking the nuclear factor- $\mathrm{\kappa B}$ p65 activation. Veterinary Microbiology 2020, 251, https://doi.org/10.1016/j.vetmic.2020.108892.

83. Banerjee, A.; Czinn, S.J.; Reiter, R.J.; Blanchard, T.G. Crosstalk between endoplasmic reticulum stress and anti-viral activities: A novel therapeutic target for COVID-19. Life Sci. 2020, 255, https://doi.org/10.1016/j.lfs.2020.117842.

84. Köseler, A.; Sabirli, R.; Gören, T.; Türkçüer, I.; Kurt, Ö. Endoplasmic Reticulum Stress Markers in SARSCOV-2 Infection and Pneumonia: Case-Control Study. In Vivo 2020, 34, 1645-1650, https://doi.org/10.21873/invivo.11956.

85. García-Pérez, B.E.; González-Rojas, J.A.; Salazar, M.I.; Torres-Torres, C.; Castrejón-Jiménez, N.S. Taming the Autophagy as a Strategy for Treating COVID-19. Cells 2020, 9, https://doi.org/10.3390/cells9122679.

86. Domdom, M.-A.; Brest, P.; Grosjean, I.; Roméo, B.; Landi, M.T.; Gal, J.; Klionsky, D.J.; Hofman, P.; Mograbi, B. A multifactorial score including autophagy for prognosis and care of COVID-19 patients. Autophagy 2020, 16, 2276-2281, https://doi.org/10.1080/15548627.2020.1844433.

87. Gorshkov, K.; Chen, C.Z.; Bostwick, R.; Rasmussen, L.; Xu, M.; Pradhan, M.; Tran, B.N.; Zhu, W.; Shamim, K.; Huang, W.; Hu, X.; Shen, M.; Klumpp-Thomas, C.; Itkin, Z.; Shinn, P.; Simeonov, A.; Michael, S.; Hall, M.D.; Lo, D.C.; Zheng, W. The SARS-CoV-2 cytopathic effect is blocked with autophagy modulators. bioRxiv : the preprint server for biology 2020, 2020, https://doi.org/10.1101/2020.05.16.091520.

88. Ren, Y.; Shu, T.; Wu, D.; Mu, J.; Wang, C.; Huang, M.; Han, Y.; Zhang, X.-Y.; Zhou, W.; Qiu, Y.; Zhou, X. The ORF3a protein of SARS-CoV-2 induces apoptosis in cells. Cellular \& Molecular Immunology 2020, 17, 881-883, https://doi.org/10.1038/s41423-020-0485-9.

89. Si, F.; Hu, X.; Wang, C.; Chen, B.; Wang, R.; Dong, S.; Yu, R.; Li, Z. Porcine Epidemic Diarrhea Virus (PEDV) ORF3 Enhances Viral Proliferation by Inhibiting Apoptosis of Infected Cells. Viruses 2020, 12, https://dx.doi.org/10.3390\%2Fv12020214.

90. Singh Tomar, P.P.; Arkin, I.T. SARS-CoV-2 E protein is a potential ion channel that can be inhibited by Gliclazide and Memantine. Biochem. Biophys. Res. Commun. 2020, 530, 10-14, https://doi.org/10.1016/j.bbrc.2020.05.206.

91. Bai, D.; Fang, L.; Xia, S.; Ke, W.; Wang, J.; Wu, X.; Fang, P.; Xiao, S. Porcine deltacoronavirus (PDCoV) modulates calcium influx to favor viral replication. Virology 2020, 539, 38-48, https://doi.org/10.1016/j.virol.2019.10.011.

92. Ye, C.; Chiem, K.; Park, J.G.; Oladunni, F.; Platt, R.N., 2nd; Anderson, T.; Almazan, F.; de la Torre, J.C.; Martinez-Sobrido, L. Rescue of SARS-CoV-2 from a Single Bacterial Artificial Chromosome. mBio 2020, 11, e02168-20, https://doi.org/10.1128/mBio.02168-20.

93. Xie, X.; Muruato, A.; Lokugamage, K.G.; Narayanan, K.; Zhang, X.; Zou, J.; Liu, J.; Schindewolf, C.; Bopp, N.E.; Aguilar, P.V.; Plante, K.S.; Weaver, S.C.; Makino, S.; LeDuc, J.W.; Menachery, V.D.; Shi, P.-Y. An Infectious cDNA Clone of SARS-CoV-2. Cell Host \& Microbe 2020, 27, 841-848.e843, https://doi.org/10.1016/j.chom.2020.04.004.

94. Chiem, K.; Morales Vasquez, D.; Park, J.G.; Platt, R.N.; Anderson, T.; Walter, M.R.; Kobie, J.J.; Ye, C.; Martinez-Sobrido, L. Generation and Characterization of recombinant SARS-CoV-2 expressing reporter genes. J. Virol. 2021, 95, e02209-20, https://doi.org/10.1128/jvi.02209-20.

95. Xie, X.; Muruato, A.E.; Zhang, X.; Lokugamage, K.G.; Fontes-Garfias, C.R.; Zou, J.; Liu, J.; Ren, P.; Balakrishnan, M.; Cihlar, T.; Tseng, C.-T.K.; Makino, S.; Menachery, V.D.; Bilello, J.P.; Shi, P.-Y. A nanoluciferase SARS-CoV-2 for rapid neutralization testing and screening of anti-infective drugs for COVID-19. Nature Communications 2020, 11, https://doi.org/10.1038/s41467-020-19055-7.

96. Silvas, J.A.; Vasquez, D.M.; Park, J.G.; Chiem, K.; Allué-Guardia, A.; Garcia-Vilanova, A.; Platt, R.N.; Miorin, L.; Kehrer, T.; Cupic, A.; Gonzalez-Reiche, A.S.; Bakel, H.V.; García-Sastre, A.; Anderson, T.; Torrelles, J.B.; Ye, C.; Martinez-Sobrido, L. Contribution of SARS-CoV-2 Accessory Proteins to Viral Pathogenicity in K18 Human ACE2 Transgenic Mice. J Virol 2021, 95, https://doi.org/10.1128/jvi.0040221.

97. Keep, S.; Oade, M.S.; Lidzbarski-Silvestre, F.; Bentley, K.; Stevenson-Leggett, P.; Freimanis, G.L.; Tennakoon, C.; Sanderson, N.; Hammond, J.A.; Jones, R.C.; Britton, P.; Bickerton, E. Multiple novel noncanonically transcribed sub-genomic mRNAs produced by avian coronavirus infectious bronchitis virus. The Journal of general virology 2020, 101, 1103-1118, https://doi.org/10.1099/jgv.0.001474.

98. Finkel, Y.; Mizrahi, O.; Nachshon, A.; Weingarten-Gabbay, S.; Morgenstern, D.; Yahalom-Ronen, Y.; Tamir, H.; Achdout, H.; Stein, D.; Israeli, O.; Beth-Din, A.; Melamed, S.; Weiss, S.; Israely, T.; Paran, N.; Schwartz, 
M.; Stern-Ginossar, N. The coding capacity of SARS-CoV-2. Nature 2021, 589, 125-130, https://doi.org/10.1038/s41586-020-2739-1.

99. Nelson, C.W.; Ardern, Z.; Goldberg, T.L.; Meng, C.; Kuo, C.H.; Ludwig, C.; Kolokotronis, S.O.; Wei, X. Dynamically evolving novel overlapping gene as a factor in the SARS-CoV-2 pandemic. eLife 2020,9, https://doi.org/10.7554/eLife.59633.

100.Peng, Q.; Fang, L.; Ding, Z.; Wang, D.; Peng, G.; Xiao, S. Rapid manipulation of the porcine epidemic diarrhea virus genome by CRISPR/Cas9 technology. J. Virol. Methods 2020, 276, https://doi.org/10.1016/j.jviromet.2019.113772. 